\title{
Improvisação, uma necessidade
}

\author{
Marcelo LAZZARATTO ${ }^{1}$ \\ Universidade Estadual de Campinas - Unicamp \\ A improvisação me interessa como o lugar do encontro \\ de um objeto estrangeiro, exterior ao jogador, com o imaginário deste. \\ Ela provoca o sujeito a reagir, seja no interior da proposta que lhe é feita, \\ seja em torno da proposta, explorando amplamente a zona que se \\ desenha para ele, segundo o modo como sua imaginação é convocada.
}

(RYNGAERT, 2009, p. 90)

Os artistas envolvidos na criação teatral, principalmente atores e diretores, utilizam em alguma etapa do processo criativo a Improvisação. Para a desinibição dos atores, para o estímulo à espontaneidade, para a análise ativa das relações e dos objetivos dos personagens, para a descoberta de possível material criativo que não é oferecido a priori pelo texto a ser encenado, para conquistar interação entre os atores envolvidos no jogo teatral, para desenvolver rapidez de raciocínio e prontidão, para colocar-se em uma situação buscando envolvimento, para oferecer aos atores a possibilidade de descoberta pessoal, para verificação das características dos personagens e para tantas outras coisas que a lista seria quase que infindável.

A Improvisação se presta a qualquer momento do processo. Cabe aos artistas envolvidos perceberem a sua utilidade a partir de suas necessidades. De Stanislavski a Peter Brook, passando por Brecht, Barba, Viola Spolin, Stela Adler, Michail Checov, Boal e Grotovski, todos em algum momento de suas criações e de seus sistemas de trabalho usam a Improvisação de acordo com suas teorias. Cada um ao seu modo propõe aos atores que improvisem oferecendo limites seja de linguagem, de objetivos, ou de traços estilísticos que pertençam à sua proposta estética.

Assim, nunca se falou e nem é possível falar em um método de Improvisação, pois traria em si uma contradição incontornável. Um método traz em sua essência uma ideia de finitude, acabada, uma fórmula pela qual se chega a um resultado já comprovado e verificado. Ora, a Improvisação é exatamente o oposto. Ela nunca será um fim e sim um meio. Não é possível dizer que se você fizer de tal e tal maneira num improviso você chegará a tal resultado, pois ela abre, durante seu acontecer, inúmeras possibilidades, que uma vez desenvolvidas, podem chegar

\footnotetext{
${ }^{1}$ Marcelo Lazzaratto é ator, diretor, pesquisador teatral e Doutor em Artes. Leciona no Depto. de Artes Cênicas da Unicamp e é diretor artístico da Cia. Elevador de Teatro Panorâmico. Publicou em 2011 o livro O campo de visão: exercício e linguagem cênica. E-mail: marevi@uol.com.br.
} 
a resultados diversos, tantas vezes quantas for realizada. Nunca se saberá ao certo qual será o fim de um Improviso. Ele dependerá de inúmeras variantes subjetivas que dizem respeito somente aos artistas que o executam.

É por isso que cada artista, cada diretor de teatro, estimula seus atores a sua maneira e encontra na Improvisação uma aliada que se adequa muito bem às suas características. Um diretor nem sempre se adequa à Improvisação, mas a Improvisação sempre se adequa ao diretor. Essa adequação ocorre devido ao fato de a Improvisação, além de ser um procedimento de treinamento, se constituir também como linguagem. Assim, ela cabe muito bem, por ser tão maleável, às exigências estéticas da encenação.

Mas os autores de maneira geral não se dedicam em seus textos à Improvisação como poderiam ou deveriam. Em seus livros se preocupam em conceituar princípios estéticos inovadores que tragam uma nova luz à cena, sentindo a necessidade do ponto final e da comprovação de sua investigação; e a Improvisação, por ser um meio e não um fim, não se presta a essa finalidade. Por ser muito difundida, utilizada por todos em todos os processos, é como se fosse um lugar-comum óbvio demais (a redundância aqui é necessária) para se prestar à inovação pretendida.

Ao contrário, creio que é por isso que deva ser valorizada e muito.

Mas como falar de Improvisação, oferecer seu real valor se ela em si é efêmera? Usar que metodologia para destrinchá-la?

Se o Teatro é efêmero, o Improviso é sua potencialização máxima. Tanto que requer muita disciplina e concentração para que os artistas recuperem momentos enriquecedores descobertos em uma Improvisação. Não há registro, como no improviso jazzístico. O vídeo, como todos sabem, não guarda sensorialidades que somente o calor da execução oferece. Sensorialidades advindas de um processo intuitivo de apreensão.

A intuição, além de ser algo extremamente valioso para qualquer artista, já que se refere a um conhecimento existente, imediato, mas não elaborado como discurso, traz à luz percepções apreendidas em algum momento que, ao se tomar partido delas, o ator lança-se em um terreno movediço que certamente será transformador. $\mathrm{O}$ ator, por ser alguém que encontra na prática sua razão de ser, seu entendimento, necessita da experimentação para compreender seus processos criativos. Ele não é um teórico que encontra unicamente no pensar a chave de seu ofício: não é somente o conhecimento lógico-racional que é válido para ele. Ele também está sujeito à experiência, levando em conta os sentimentos e as vontades frentes a ela. Seu 
conhecimento não é, portanto, somente do tipo racional-discursivo, mas também, do tipo irracional-intuitivo. A experiência o transforma, pois o desequilibra. É no desequilíbrio que se descobre novos prumos, novas possibilidades inventivas. A Improvisação promove um desequilíbrio do "já conhecido", já que opera, e muito, segundo e seguindo a intuição. Faz com que o ator ande na corda bamba em busca de um novo eixo, que se estabelecerá a cada dia e sempre sendo um novo eixo, sujeito às necessidades e variáveis da criação.

$\mathrm{Na}$ questão metodológica o problema se mostra com muita clareza, mas com pouca resolução. Que método abarcará as inúmeras variáveis proporcionadas por um procedimento que traz em sua essência processos intuitivos? Como já dito acima, a Improvisação não se adequa a um método. Brincando com termos da Física Quântica, ela está mais para onda do que para partícula. Pode estar nesse e/ou naquele registro. Servir a tal e/ou tal estilo. É capaz de multifacetar-se, está mais para reticências do que para ponto final.

Então, como demonstrá-la, como dar validade científica?

Se levarmos em consideração que a Improvisação é uma prática e os atores seres humanos que querem e sentem em busca do conhecimento, a intuição será sua grande aliada. Johannes Hessen em seu livro Teoria do conhecimento ao discutir sobre os problemas do intuicionismo diz:

(...) devemos fazer uma distinção. Trata-se da distinção entre o comportamento teórico e o prático. No campo teórico, a intuição não pode reclamar o direito de ser um meio de conhecimento autônomo, emparelhado ao conhecimento racional - discursivo. Nesse campo, o intelecto está com a palavra final. Toda intuição deve, aqui, legitimar-se perante o tribunal da razão. O opositor do intuicionismo está certo em fazer essa exigência. Mas as coisas já não se passam do mesmo modo no campo prático. A intuição possui, nesse terreno, uma importância autônoma. Enquanto seres que sentem e querem, a intuição é, para nós, o verdadeiro órgão do conhecimento. Se o que o intuicionismo ensina não é nada mais do que isso, a razão está do seu lado. (HESSEN, 2000, p. 110)

Acredito que o melhor método para investigar a Improvisação não é um método e sim um sistema, um sistema dinâmico que leva em conta as variáveis. Tal sistematização leva em conta a ideia de repetição, não fechando portas, mas permitindo a existência de lacunas originadas nas repetições, detectando e analisando as variáveis para que ocorra nova sistematização, num processo constante e ininterrupto. É por isso que há a necessidade de treinamento, elaboração e reflexão constantes.

Em uma época onde a ideia de arquétipo e inconsciente coletivo já tem mais de meio século e a ciência através da Física Quântica leva em conta a incerteza como dado científico, a 
probabilidade como certeza, o insight quântico como um dado inerente à criatividade, acredito que a Improvisação no teatro é o meio potencial para a verificação dessas características: lugar onde a incerteza é benéfica e transformadora, onde o a priori não tem espaço, as probabilidades verificadas, a sensorialidade estimulada até o insight e, em sintonia, a coletividade criadora instaurando uma atmosfera poética para trazer à luz ideias latentes no inconsciente.

Improvisar é alcançar a liberdade. Não uma liberdade utópica, romântica, mas sim, instaurar-se em um plano poético onde a impossibilidade não existe. A sensação dessa possibilidade leva o ator a conectar-se com prazeres até então não revelados, abrindo potencialidades de significação e compreensão que não advêm necessariamente da racionalidade. Improvisar faz o corpo pensar. Abole a divisão corpo/mente. Razão e sensibilidade juntas processando os mais variados estímulos e respondendo a eles de maneira criativa; pois nesse estado (corpo pensando), não há certo e errado, não há juízo de valor, muito menos maniqueísmos e dicotomias; o que há é o processo da dualidade, constante, entrelaçando-se em espiral como o DNA, como o anel de Moebius, onde figura e fundo coexistem, significando e dependendo um do outro.

Improvisar é abrir-se à inspiração e ao acaso. Inspiração no sentido de conexão, conexão com uma supra-consciência geradora da qual fazemos parte e que nos tira do estado de consciência cotidiano, banal e viciado para nos colocar em um estado poético de consciência, transgressor e atuante. Sentir-se inspirado é perceber a inexistência de obstáculos. É perceber a fluência em lugar do tranco. Ou melhor, levar em consideração o tranco como fluência.

Fayga Ostrower, em seu livro Acasos e criação artística, relacionando acaso e inspiração, nos diz que os acasos de alguma forma são esperados ainda que numa "expectativa inconsciente" e continua dizendo que:

é importante levar em consideração este ponto: o de uma expectativa latente em nós, em termos de mobilização psíquica e receptividade. Iluminará certas questões de inspiração. Mostrará a distinção a ser feita entre passividade e receptividade. As pessoas não são passivas frente aos estímulos - e não é qualquer estímulo que poderá tornar-se "acaso" ou "inspiração". As pessoas estão é receptivas; receptivas, a partir de algo que já existe nela de forma potencial e que encontra no acaso como que uma oportunidade concreta de se manifestar. Por mais surpreendentes que sejam os acasos, eles nunca surgem de modo arbitrário e sim dentro de um padrão de ordenações, em que as expectativas latentes da pessoa e os termos de seu engajamento interior representam um elo vital na cadeia causa e efeito. (OSTROWER, 1999, p. 4) 
Somente nesse ponto é que chegamos ao estado de improviso. E para chegar a ele é necessário improvisar. Chega-se ao estado de improviso improvisando. Improvisação é matéria vivida. Ela faz com que não nos esqueçamos que o homem é constituído de carne, ossos, sangue e emoções. Ela nos alia, nós, atores e espectadores, novamente a forças vitais, reinstaurando-nos Dioniso. Canal aberto para o entusiasmo, no sentido que a Antiguidade nos legou: arrebatamento extraordinário daqueles que estavam sob inspiração divina. Caminho da espontaneidade que nos leva ao humor e à leveza, alargando e aprofundando as possibilidades criativas.

Por outro lado o "vale tudo" da Improvisação pode nos levar ao "qualquer coisa". Um dos motivos pelos quais a Improvisação cai em descrédito é essa sua queda pela falta de rigor quando utilizada com incompetência. Por ser algo dinâmico, repleto de variáveis, que não visa exatamente um fim, mas entende que o caminho é a questão, a Improvisação exige que os atores e diretores processem seu fazer operando de uma outra forma. Uma reflexão mecanicista não suporta as variáveis do Improviso. Esse tipo de pensamento tende a querer resultados específicos e imediatos, tende a equacionar todas as coisas visando finais certeiros e reprodutíveis. A Improvisação exige uma mudança de paradigma. Ela nos ajuda a compreender que a arte do ator não é fixa, que a ação que ele fará amanhã em cena não é (mesmo) a mesma de hoje. Que sua reprodução é dependente de variáveis ao mesmo tempo objetivas e subjetivas, racionais e sensoriais, previstas e irremediavelmente ligadas ao acaso. Por isso deve-se adquirir uma nova forma de processar a Improvisação tanto no momento de seu acontecimento quanto no momento de sua reflexão.

O compositor, regente e educador Hans-Joachin Koellreutter a respeito da Improvisação em música e que se estende a qualquer Improvisação artística diz:

Não há nada que precise ser mais planejado do que uma Improvisação. Para improvisar é preciso definir claramente os objetivos que se pretende atingir. É preciso ter um roteiro, e a partir daí trabalhar muito: ensaiar, experimentar, refazer, avaliar, criticar, etc.. O resto é vale-tudismo! (BRITO, 2001, pp. 45-6)

Acrescentaria ao planejamento que os artistas envolvidos em uma Improvisação devam também estar abertos a compreenderem/sentirem a ideia/sensação de fluência, dinâmica, mobilidade, impregnação, aleatoriedade. Planejar para lançar-se. Saber que planejamos a vela, o mastro, as cordas, mas não o vento. Prevemos o vento, mas não o dominamos. A Improvisação 
ensina-nos a controlar sem controle. Por isso sua potência. Por isso ela desestabiliza e oferece o inesperado, o "novo".

Improvisação é coisa séria. Não pode ser entendida apenas como "gambiarra", como mascaramento de um erro, mas sim como meio de acesso à criatividade. É através dela que o ator encontrará o meio pelo qual expressará suas necessidades e desejos. O ator que não se lança ao improviso deixa de perceber que é através dele que sua necessidade de expressão pode se manifestar. Porque a Improvisação é o seu território, um território vivo. Ele pode, assim, subjugar-se à necessidade do autor e do diretor. Deixa de estabelecer um diálogo com tais necessidades. Ele deixa de ser artista e passa a ser um mero executor de tarefas. Ele perde contato consigo, deixa de perceber-se como homem inserido em um contexto em que todas as vozes devem ser ouvidas e compartilhadas. Impede seu grito.

Michael Chechov, em seu livro Para o ator, a respeito de Improvisação diz que:

Pensadores profundos, impelidos a expressarem-se, criaram seus próprios sistemas filosóficos. Do mesmo modo, um artista que se esforça por expressar suas convicções mais íntimas trata de aperfeiçoar seus próprios instrumentos de expressão, sua forma particular de arte. O mesmo, sem exceção, deve ser dito da arte do ator: seu desejo irrefreável e seu mais alto propósito também só podem ser satisfeitos por meio da livre Improvisação (CHECOV, 1986, p. 39).

Embora a Improvisação seja um procedimento que sempre existiu, às vezes com mais intensidade, como nos autos medievais e na Comédia dell'arte, outras vezes de maneira mais sutil como no Classicismo francês, é no século XX, com a modernidade, que ela ganha espaço definitivo nas manifestações artísticas: na música dita erudita de Stravinsky a Koellreutter passando por Cage; na popular com o aparecimento do Jazz nos Estados Unidos, onde a Improvisação é o próprio jazz, ou nos repentes nordestinos; nas artes plásticas através do conceito de Instalação levando em conta o visitante, relacionando-se com a obra de maneira improvisada e aleatória, os Parangolés de Hélio Oiticica sendo um exemplo próximo; e no teatro, a ideia de Performance Teatral advinda dos anos 60 com o Living Theatre.

$\mathrm{Na}$ contemporaneidade, neste momento em que o ator passa a ser o centro das atenções, onde o conceito ator-criador é amplamente divulgado (embora o considere uma redundância), em que o diálogo ator/encenador se dá de maneira mais franca e democrática, a Improvisação é o melhor instrumento de pesquisa para que esse ator possa se manifestar, 
elaborar o seu material criativo, associar fundamentos teóricos com a ação cênica especificamente, enfim, entrar em contato com suas necessidades e anseios expressivos.

Peter Brook nos diz:

"Vamos supor que tenhamos a mais elevada das ambições: no espetáculo, só queremos apanhar o peixe dourado" (entenda-se peixe dourado como a qualidade especial que faz com que a arte se manifeste plenamente e alcance todos os espectadores tanto a nível racional quanto intuitivo). De onde vem o peixe dourado? Ninguém sabe. Deve ser de algum lugar do inconsciente coletivo mítico, daquele vasto oceano cujos limites nunca foram descobertos, cujas profundezas nunca foram suficientemente exploradas. E onde estamos nós, as pessoas comuns da plateia? Estamos no mesmo lugar em que estávamos ao entrar no teatro, em nós mesmos, em nossas vidas corriqueiras. Tecer a rede (para apanhar o peixe dourado) é construir uma ponte entre nós, como somos habitualmente em condições normais, trazendo conosco nosso mundinho de todo dia, e um mundo invisível que só pode se revelar quando a insuficiência da percepção ordinária é substituída por outro tipo de consciência cuja qualidade é infinitamente mais aguda. Mas essa rede é feita de buracos ou de nós? Esta questão é como um koan, e para fazer teatro devemos conviver com ela o tempo todo. (BROOK, 1999, p. 72)

Peter Brook talvez seja o grande mestre da arte de interpretar da última metade do século XX. Mestre, porque além de exigir de seus atores qualidades técnicas fundamentais para a fruição da energia humana transformada em arte, ele também se preocupa, como acabamos de ver, com questões "abstratas", subjetivas e ocultas, tais como, atmosfera da cena, relação energética palco-plateia, oferecer ao ator e posteriormente à plateia condições de ampliar a percepção consciente cotidiana para alcançar uma nova percepção, oriunda da intuição que está profundamente conectada com o inconsciente coletivo.

Assim, o ator pode recuperar sensações, cheiros, gestos de uma ancestralidade para muitos perdida e articulá-los na ação cênica. Ao entrarmos em contato com essa grande consciência percebemos que o Tempo não é o mesmo tempo cronológico do dia-a-dia, o Espaço já não é esse que ocupamos diariamente, e o que observamos é uma outra relação tempo-espaço, um lugar de simultaneidades e sincronicidades onde tudo é possível, tudo é provável, basta estarmos antenados para "sacar" os sinais, seus indícios.

Peter Brook exercita seus atores para que afinem seus instrumentos de trabalho (corpo pensando) em busca dessa nova qualidade de percepção. Porque se trata de uma percepção criativa. Esse estado dilatado de entendimento - que aqui traduzo por corpo-pensando, mesclando o que é da mente e o que é do corpo - precisa de um terreno, de um laboratório em 
que suas químicas se misturem e se potencializem a tal ponto que não possamos mais perceber quem gestou a faísca criativa. E acredito que a improvisação para o ator é esse terreno fértil.

Em um processo improvisacional é mais fácil percebermos e detectarmos o instante em que ocorre em nós a criatividade. Para jogar com as inúmeras variáveis que ele nos apresenta só mesmo com criatividade. Há um estado de latência constante que faz com que o gesto, o movimento, a ação, desempenhados pelo ator, em sua ação improvisada, adquira a força da espontaneidade, por ter sido escolhida entre tantas outras possibilidades. Essa escolha é a resultante do impulso advindo da intuição com a ordenação e a estruturação advindas da consciência.

É através dela que o ator tem a oportunidade de acessar livremente uma região potencial criativa por excelência que aparece do encontro entre sua sensibilidade e o material poético, entre sua individualidade e o “outro". É nessa região potencial que o gesto criador pode adquirir forma e assim se expressar na cena propriamente dita segundo os critérios estéticos de cada encenação.

Se o ator é essencialmente um artista que manifesta em seu próprio corpo a sua arte, ele não pode ficar alheio ao "outro" acreditando apenas em sua própria capacidade inventiva. É somente através do contato com o "outro" que ele tem a possibilidade de se tornar verdadeiramente um criador e o jogo improvisacional é o lugar ideal para que esse exercício da alteridade se dê plenamente.

A improvisação é um território ao mesmo tempo fecundo e movediço em que ele encontra a fluidez criativa originada do encontro entre as latências inconscientes e as escolhas conscientes. É no jogo improvisacional que o ator encontra o élan vital de sua arte.

\section{BIBLIOGRAFIA CITADA:}

BRITO, Teca Alencar de. Koellreutter Educador: o bumano como objetivo da educação musical. São Paulo, Peirópolis, 2001.

BROOK, Peter. A porta aberta. Rio de Janeiro, Civilização Brasileira, 1999. CHECHOV, Michael. Para o ator. São Paulo, Martins Fontes, 1986. HESSEN, Johannes. Teoria do conhecimento. São Paulo, Martins Fontes, 2000. RYNGAERT, Jean-Pierre. Jogar, representar. São Paulo, Cosac e Naify, 2009. OSTROWER, Fayga. Acasos e criação artística. Rio de Janeiro, Campus, 1999. 


\begin{abstract}
This article intends to, besides pointing how important is improvisation to the creative process of an actor, show that is through improvisation that the actor finds an infinite source to turn his actions into art. This article discusses the problem of a methodology to improvisation and relies on its ephemerality and variety of possibilities as essential elements for the actor to open his perceptivity, pulling down the dichotomy between sense and sensibility.
\end{abstract}

Keywords: Improvisation; alterity; acting. 